\title{
PENGARUH BENTUK PIN TERHADAP SIFAT MEKANIK ALUMINIUM 5083 - H112 HASIL PROSES FRICTION STIR WELDING
}

\author{
THE EFFECT OF PIN DESIGN ON MECHANICAL PROPERTIES OF \\ ALUMINIUM 5083 - H112 AS A RESULT OF FRICTION STIR WELDING \\ PROCESS
}

\author{
Irfan Helmi dan Tarmizi \\ Balai Besar Logam dan Mesin Bandung \\ irfan@kemenperin.go.id
}

Diterima : 27-01-2017

Direvisi : 07-03-2017

Disetujui : 12-05-2017

\begin{abstract}
ABSTRAK
Proses las aduk gesek yang merupakan pengelasan kondisi padat memanfaatkan gesekan tool dengan benda kerja untuk melunakkan material yang disambung menjadi pilihan dalam pengelasan aluminium. Pemilihan tool yang tepat akan menghasilkan lasan dengan sifat mekanik yang baik. Penelitian ini bertujuan untuk mengetahui pengaruh bentuk pin yang berbeda terhadap sifat mekanik dan struktur mikro hasil lasan menggunakan proses pengelasan aduk gesek. Proses las aduk gesek dengan cara tool berputar melakukan penetrasi ke benda kerja dan gesekan akan melunakkan material. Sambungan terbentuk akibat bersatunya logam lunak pada kedua sisi dengan adanya tekanan tool. Proses las aduk gesek aluminium 5083 - H112 menggunakan mesin frais dan tool dengan bentuk pin tirus beralur, silinder beralur dan segitiga beralur dengan parameter putaran tool $1500 \mathrm{rpm}$, kecepatan pengelasan $29 \mathrm{~mm} / \mathrm{min}$, sudut kemiringan tool $0^{\circ}$ dan kedalaman pembenaman pin $4,8 \mathrm{~mm}$ menunjukkan proses berlangsung dengan baik. Hasil pengujian mekanik menunjukkan nilai kekerasan sebesar $85 \mathrm{HV}$ dan harga impak rata - rata di sambungan las sebesar $0,24 \mathrm{~J} / \mathrm{mm}^{2}$ menggunakan pin tirus beralur lebih tinggi dibandingkan dengan menggunakan pin silinder beralur dan segitiga beralur. Kekuatan tarik tertinggi menggunakan pin tirus beralur sebesar $172 \mathrm{MPa}$ masih lebih rendah dari kekuatan tarik logam induk sebesar $331 \mathrm{MPa}$ karena adanya cacat pada hasil lasan. Pengamatan struktur mikro menunjukkan butir menjadi lebih halus di daerah daerah adukan dibandingkan daerah Thermomechanically Affected Zone, Heat Affected Zone dan logam induk. Proses pengelasan aduk gesek aluminium 5083 - H112 menggunakan tool dengan pin tirus beralur menghasilkan sifat mekanik dan struktur mikro yang lebih baik daripada menggunakan pin silinder beralur atau segitiga beralur.
\end{abstract}

Kata kunci : kondisi padat, las aduk gesek, frais, pin, daerah adukan

\begin{abstract}
Friction Stir Welding process, which is a solid state welding tool utilizing friction with the workpiece to soften the material is spliced into a choice in aluminum welding. Selection of the proper tool will produce welds with excellent mechanical properties. The research objective is to determine the effect of different forms of pins on mechanical properties and microstructure joint of the friction stir welding process. Friction stir welding process by means of a rotating tool to penetrate into the work piece and friction will soften the material. The connection formed by the merging of soft metal on both sides with a pressure tool. The process of friction stir welding aluminum 5083 - H112 using milling machines and tool with a tapered pin grooves, a cylinder pin grooves or a triangular pin groove and using $1500 \mathrm{rpm}$ tool rotation, the welding speed of $29 \mathrm{~mm} / \mathrm{min}, 0^{\circ}$ tool tilt angle, and the depth of plunge $4.8 \mathrm{~mm}$ indicate the process is going well. Mechanical testing indicates hardness value using is $85 \mathrm{HV}$ and impact value is $0.24 \mathrm{~J} / \mathrm{mm}^{2}$ using a tapered pin groove higher than the cylindrical pin groove and a triangular pin groove. The highest tensile strength used a tapered pin groove of 172 MPa is still lower than the base metal tensile strength of $331 \mathrm{MPa}$ because there was defect in the weldment. Microstructure observation showed changes into a finer grain in the weld nugget compared Thermomechanically area Affected Zone, Heat Affected Zone and the parent metal. Friction
\end{abstract}


Stir Welding process aluminum 5083 - H112 using a tapered pin grooves tool provide better results than that using a cylinder pin grooves or a triangular pin groove.

Keywords : solid state, FSW, milling, probe, Weld Nugget

\section{PENDAHULUAN}

luminium dan paduan aluminium
termasuk logam ringan yang
memiliki kekuatan tinggi, tahan terhadap karat dan merupakan konduktor listrik yang baik. Aluminium memiliki ductility yang baik pada kondisi yang dingin dan memiliki daya tahan korosi yang tinggi (Tarmizi dan Prayoga, 2016). Resistansi terhadap korosi terjadi akibat fenomena pasivasi, yaitu terbentuknya lapisan aluminium oksida ketika aluminium terpapar dengan udara bebas. Jika kita lihat dari properties dan fungsinya alumunium sangatlah banyak digunakan secara luas dalam bidang transportasi, kimia, listrik, konstruksi dan peralatan penyimpanan. Untuk proses pengelasan aluminium biasanya menggunakan Gas Tungsten Arc Welding (GTAW) atau Gas Metal Arc Welding (GMAW). Namun yang menjadi kendala dalam proses pengelasannya adalah aluminum merupakan penghantar panas yang baik, mempunyai titik lebur (melting point) yang rendah dan adanya lapisan oksida pada permukaan sehingga sangat sulit untuk memanaskan atau mencairkan hanya sebagian kecil dari alumunium tersebut (Wiryosumarto, 2000). Oleh karena itu sifat mampu las alumunium dinilai kurang baik jika dibandingkan dengan baja (Prayoga, 2014).

Masalah yang timbul pada pengelasan aluminium tersebut bisa diatasi dengan proses Friction Stir Welding (FSW), karena pengelasan ini tidak menggunakan busur las. FSW adalah salah satu metode pengelasan solid state dimana hasil sambungan las terbentuk tanpa melalui pelelehan material. FSW memanfaatkan panas yang dihasilkan dari gesekan antara benda kerja dan tool yang berputar, sedangkan penyambungan material merupakan hasil dari deformasi plastis akibat adukan pin di lokasi pengelasan (Terry, 2005).
Parameter pengelasan yang umum digunakan dalam proses FSW antara lain geometri tool, kecepatan putar tool (rpm), kecepatan translasi tool $(\mathrm{mm} / \mathrm{min})$, dan sudut kemiringan tool (Mishra dan Mahoney, 2007). Geometri tool khususnya pada profil pin memberikan pengaruh yang besar terhadap pemanasan dan aliran perpindahan material. Desain profil pin yang berbeda akan menghasilkan kualitas sambungan yang berbeda, dan perubahan sifat mekanis serta struktur mikro pada hasil sambungan juga akan berbeda (Terry, 2005).

Untuk mengetahui pengaruh profil pin khususnya pada material paduan aluminium jenis 5083, maka dilakukan penelitian terhadap hasil sambungan proses FSW dengan menggunakan beberapa variasi desain profil pin. Penelitian ini bertujuan melakukan proses Friction Stir Welding paduan aluminium 5083 - H112, mendapatkan parameter pengelasan yang optimum pada proses Friction Stir Welding untuk material aluminium 5083 - H112 dan mengetahui sifat mekanik lasan hasil proses Friction Stir Welding dan analisis struktur mikro yang terbentuk hasil proses Friction Stir Welding serta mengetahui kemampuan tool dan bentuk pin yang cocok pada proses Friction Stir Welding Aluminium $5083-\mathrm{H} 112$.

Konsep dasar FSW adalah sangat sederhana, yaitu sebuah nonconsumable tool dengan bagian pin dan shoulder yang dirancang khusus berputar kemudian dibenamkan ke dalam titik awal sambungan dan selanjutnya bergerak translasi sepanjang joint line (Mishra dan Mahoney, 2007). Gerakan relatif putaran shoulder dan pin terhadap benda kerja yang diam menghasilkan panas akibat gesekan yang dapat melunakkan material benda kerja tanpa mencapai titik leburnya (melting point). Kemudian gerak putar dan 
translasi tool mengakibatkan material lunak berpindah dari sisi depan pin menuju sisi belakang pin sambil menerima tekanan dari shoulder sehingga terbentuklah sambungan las (Mishra dan Mahoney, 2007). Proses pengelasan terjadi ketika tool bergerak pada jalur pengelasan (joint line) dari material yang akan disatukan dengan kecepatan tetap (Rahayu, 2012). Prinsip kerja FSW ditunjukan pada Gambar 1 :

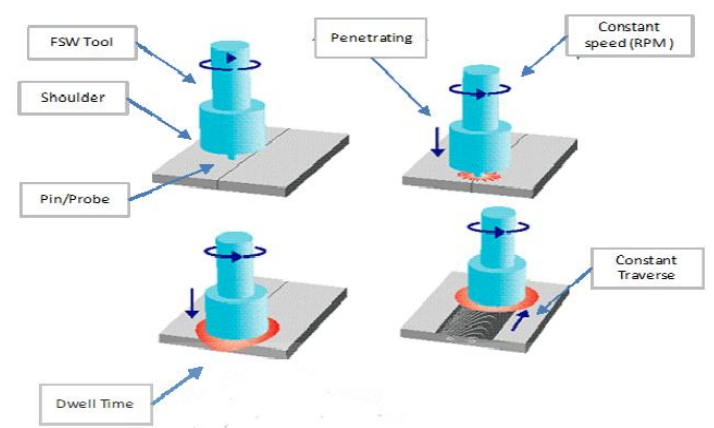

Gambar 1. Prinsip kerja proses FSW

Menurut Rajiv S Mishra dan Murray W. Mohoney (2007) Proses FSW menghasilkan weld zone yang dibagi menjadi beberapa bagian seperti yang ditunjukkan Gambar 2:

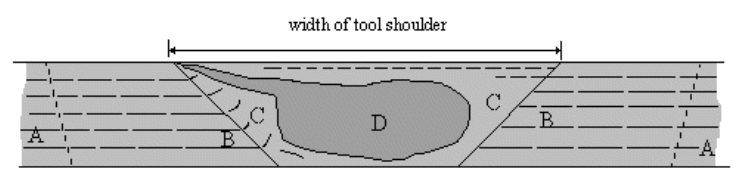

Gambar 2. Struktur mikro hasil pengelasan dengan metode FSW A. Base metal B. Heat Affected Zone C. Thermeomechanically Affected Zone D. Weld Nugget

Base Metal, Area logam induk yang tidak terkena pengaruh panas yang dihasilkan selama proses FSW berlangsung.

> Heat-Affected Zone HAZ, Daerah yang tidak pernah mencair dan tidak mengalami deformasi plastis tetapi mengalami perubahan struktur mikro dan sifat mekanik akibat terpengaruh panas.

> Thermomecanically Affected Zone TMAZ, Daerah yang tidak pernah mencair dan tidak mengalami

rekristalisasi tetapi mengalami deformasi plastis yang menyebabkan terjadi perubahan struktur mikro akibat pengaruh panas. Dan ada batas yang membedakan antara area weld nugget dan area TMAZ yang terdeformasi.

Weld Nugget, Area yang secara utuh mengalami rekristalisasi atau terkadang disebut juga Stir Zone. Area ini merupakan area yang menghasilkan sambungan akibat gerakan tool.

Aluminium seri 5 adalah tipe paduan Al-Mg yang tidak dapat diperbaiki sifat mekaniknya dengan perlakuan panas, sehingga dinamakan non heat treatable alloy (ESAB, 2012). Komposisi kimia dari aluminium 5083 - H112 ditunjukkan pada Tabel 1:

Tabel 1. Komposisi kimia aluminium 5083 (ASM, 2004)

\begin{tabular}{lc}
\hline \multicolumn{1}{c}{ Elemen } & \% Berat \\
\hline Silikon, $\mathrm{Si}$ & $0.4-0.7$ \\
Besi, $\mathrm{Fe}$ & 0.4 \\
Tembaga, $\mathrm{Cu}$ & 0.1 \\
Mangan, $\mathrm{Mn}$ & $0.4-1.0$ \\
Magnesium, Mg & $4.0-4.9$ \\
Zinc, Zn & 0.25 \\
Titanium, Ti & 0.15 \\
Krom, Cr & $0.05-0.25$ \\
Aluminium, Al & Sisanya \\
\hline
\end{tabular}

Aluminium paduan seri 5083 adalah salah satu jenis aluminium paduan dengan paduan utama magnesium $(\mathrm{Mg})$ sekitar 4.5 \%. Aluminium paduan seri 5083 adalah jenis aluminium yang banyak digunakan dalam dunia industri, karena mempunyai sifat mekanik dan kemampuan mampu las yang baik. Penggunaannya adalah untuk konstruksi perkapalan dan bejana tekan (pressure vessel), towers and drilling rigs, gas/oil piping (ASM 2, 2004). 


\section{METODE PENELITIAN}

Dalam penelitian ini beberapa tahapan proses yang dilakukan pada proses FSW dapat dilihat dari diagram alir yang ditunjukkan Gambar 3.

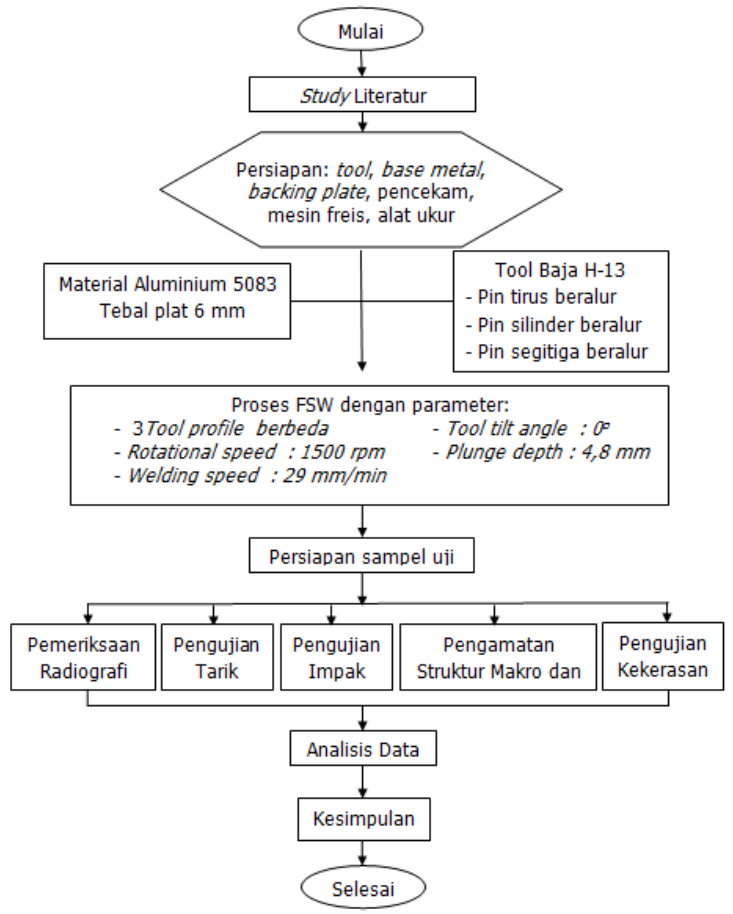

Gambar 3. Diagram alir penelitian Friction Stir Welding

Penelitian FSW yang dilakukan di Balai Besar Logam dan Mesin Bandung menggunakan mesin Milling dengan material yang disambung adalah aluminium 5083-H112 ketebalan $6 \mathrm{~mm}$ dengan ukuran $350 \mathrm{~mm}$ x $120 \mathrm{~mm}$ dan tipe sambungan butt joint menggunakan tool dengan variasi bentuk pin tirus beralur, silinder beralur dan segitiga beralur. Dimensi tool pada proses FSW ini memiliki diameter pin $5 \mathrm{~mm}$, panjang pin 5 $\mathrm{mm}$ dan diameter shoulder $15 \mathrm{~mm}$ dengan diameter alur 0,6 $\mathrm{mm}$. Tinggi alur adalah $0,4 \mathrm{~mm}$ dan jarak antar pitch 0,4 mm. Bentuk tool yang digunakan pada proses FSW ini seperti ditunjukkan pada Gambar 4.

Parameter proses FSW yang digunakan adalah putaran tool 1500 rpm, kecepatan pengelasan $29 \mathrm{~mm} / \mathrm{min}$ dan kedalaman pembenaman pin $4,8 \mathrm{~mm}$ dengan sudut kemiringan too $0^{\circ}$.
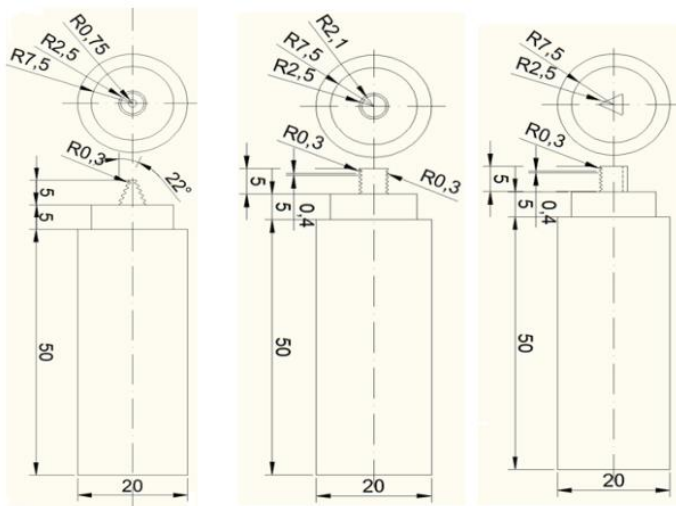

Gambar 4. Bentuk dan ukuran pin yang digunakan untuk proses FSW a) tirus beralur

b) silinder beralur c) segitiga beralur

Proses pengujian spesimen menggunakan alat - alat seperti spectrometer untuk pengujian komposisi material, $\mathrm{X}$ - Ray untuk proses radiography test, mesin uji tarik, mesin uji impak dan micro vickers untuk pengujian sifat mekaniknya serta mikroskop optik untuk melihat struktur mikro spesimen.

\section{HASIL DAN PEMBAHASAN}

Dalam Penelitian ini tool yang digunakan untuk proses FSW mempunyai bentuk seperti Gambar 5 berikut :

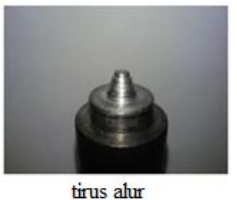

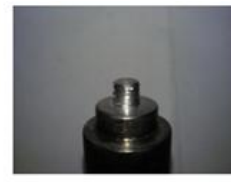

Silinder ahur

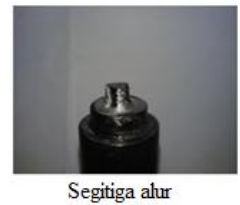

Segitiga alur
Gambar 5. Variasi bentuk pin yang digunakan untuk proses FSW (Tarmizi dan Prayoga B, 2016)

\section{Pengujian Komposisi Kimia}

Hasil pengujian menggunakan spectrometer terhadap material bahan baku paduan aluminium yang digunakan pada penelitian ini memiliki komposisi kimia seperti ditunjukan pada Tabel 2.

Dari hasil uji dengan kekuatan tarik sebesar $331 \mathrm{MPa}$ dan uji komposisi kimia maka dapat disimpulkan bahwa material yang digunakan untuk proses FSW adalah aluminium 5083 - $\mathrm{H} 112$ 
Tabel 2. Komposisi kimia aluminium 5083 H112 hasil pemeriksaan Spectroscopy

\begin{tabular}{lcc}
\hline \multirow{1}{*}{ Unsur } & \multicolumn{2}{c}{$\begin{array}{c}\text { Komposisi kimia } \\
\text { (\% berat) }\end{array}$} \\
\cline { 2 - 3 } & Aktual & $\begin{array}{c}\text { Standar Al 5083 } \\
\text { ( ASM Vol 2) }\end{array}$ \\
\hline Tembaga, Cu & 0,03 & 0,10 \\
Magnesium, & 4,36 & $4-4,9$ \\
Mg & 0,12 & 0,4 \\
Silikon, Si & 0,21 & 0,40 \\
Besi, Fe & 0,63 & $0,4-1$ \\
Mangan, Mn & 0,06 & 0,25 \\
Seng, Zn & 0,05 & 0,15 \\
Titanium, Ti & 0,06 & $0,05-0,25$ \\
Krom, Cr & 0,06 & $92,4-95,6$ \\
Aluminium, Al & 94,44 & \\
\hline
\end{tabular}

\section{Analisis Visual Hasil Pengelasan}

Hasil proses FSW secara visual dapat dilihat pada Gambar 6. Weld flash yaitu diskontinuitas permukaan yang terjadi akibat material lunak terekstrusi keluar permukaan di sekitar tool shoulder sebagai akibat volume too/yang tercelup di bawah permukaan material. (Mishra dan Ma, 2005) menegaskan bahwa banyaknya flash muncul sebagai akibat terlalu dalamnya penetrasi tool serta terlalu besarnya tool tilt angle. Keduanya menyebabkan adanya desakan ke dalam material lunak yang akhirnya muncul ke permukaan di tepi pengelasan. Desakan material keluar lebih banyak disebabkan oleh penetrasi tool dan perbedaan profil pin (Victor, 2014).

Aliran material yang terhindar dari penekanan shoulder ini mengakibatkan terbentuknya weld flash yang lebih banyak. Adanya weld flash akan mempengaruhi kekuatan sambungan, hal ini dikarenakan berkurangnya penampang sambungan yang akan menahan beban luar. Untuk mengurangi weld flash bisa dilakukan dengan mengatur kedalaman pembenaman tool atau kemiringan tool serta merubah permukaan shoulder menjadi cekung untuk menahan agar material lunak tidak keluar. Defleksi arah horizontal pada proses FSW bisa terjadi karena pencekaman benda kerja kurang kuat dan saat pelepasan klem benda kerja dalam kondisi panas.

Untuk keseluruhan sampel uji, hasil pengamatan secara visual menunjukkan bahwa defleksi yang terjadi mendekati $0^{\circ}$. Apabila mengacu pada standar atau code AWS D17.3 disebutkan bahwa flash yang terjadi akibat proses FSW harus dibersihkan setelah pengujian visual dan sebelum proses pengujian tidak merusak lainnya dilakukan.

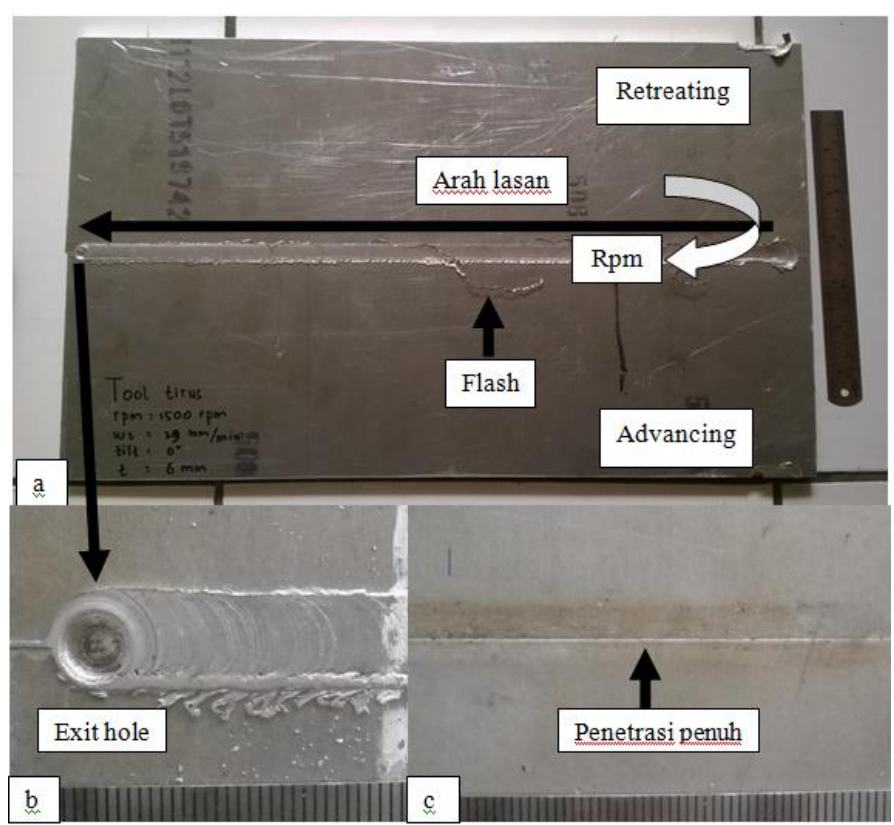

a. Tirus Beralur 


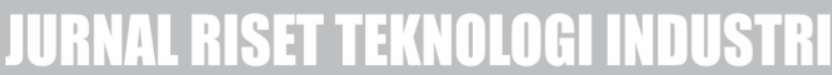

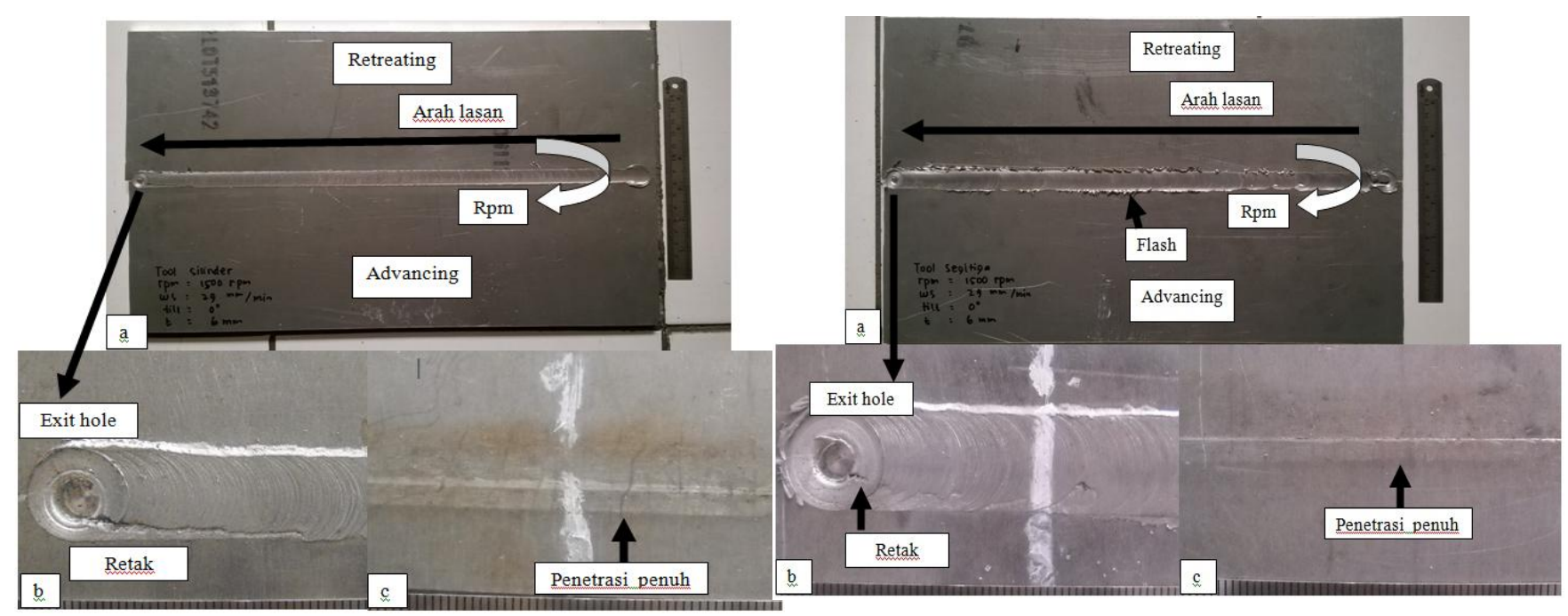

Gambar 6. Hasil pengelasan menggunakan variasi bentuk pin

Sedangkan distorsi atau defleksi yang terjadi hanya diijinkan maksimum $3^{\circ}$ sesuai menurut AWS D17.3 seperti pada Tabel 3 :

Tabel 3. Batas maksimum hasil uji cacat sesuai standar AWS D17.3

\begin{tabular}{|c|c|c|}
\hline $\begin{array}{l}\text { Jenis } \\
\text { cacat }\end{array}$ & Pengujian & $\begin{array}{c}\text { Acceptance } \\
\text { criteria }\end{array}$ \\
\hline Weld flash & $\begin{array}{l}\text { Ada flash } \\
\text { sepanjang } \\
\text { lasan }\end{array}$ & $\begin{array}{l}\text { Dibersihkan } \\
\text { setelah uji visual }\end{array}$ \\
\hline Defleksi & $0^{\circ}$ & Maksimum $3^{\circ}$ \\
\hline
\end{tabular}

\section{Analisis Hasil Pemeriksaan Radiografi}

Hasil pengujian radiografi pada proses Friction Stir Welding dengan variasi bentuk pin dapat dilihat pada Gambar 7. Berdasarkan hasil yang diperoleh dari pengujian radiografi menunjukkan adanya cacat las yaitu Incomplete Penetration pada material aluminium 5083 hasil proses FSW menggunakan tool dengan pin segitiga beralur, sedangkan pengelasan menggunakan pin silinder beralur dan tirus beralur tidak terdapat cacat.

Incomplete Penetration yang muncul pada hasil lasan menggunakan tool dengan pin segitiga beralur disebabkan oleh jarak antara ujung pin dengan bagian bawah tebal pelat terlalu besar sehingga panas yang dihasilkan akibat gesekan tidak cukup mampu melunakkan dan mengalirkan material sampai ke permukaan bawah material kerja. Desain pin diusahakan sedekat mungkin dengan bagian bawah tebal pelat tapi jangan sampai merusak anvil (landasan).

Menurut AWS D 17.3 disebutkan bahwa cacat Incomplete Penetration yang muncul akbat proses FSW tidak diijinkan sama sekali dan harus di reject.
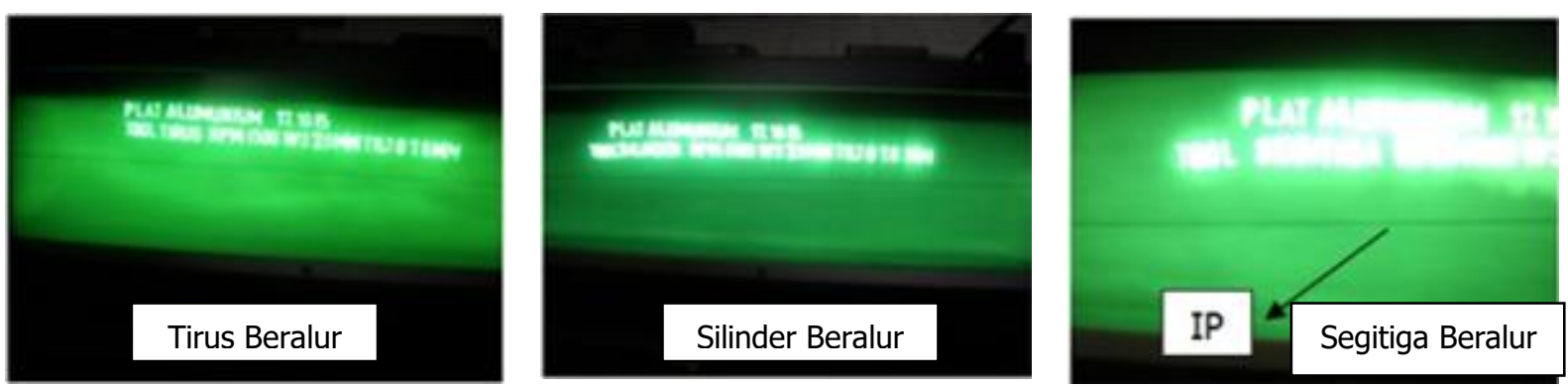

Gambar 7. Hasil Pengujian Radiografi pengelasan Aluminium 5083-H112 dengan variasi bentuk pin 


\section{Analisis Cacat}

Untuk mengetahui adanya cacat pada hasil proses FSW maka dilakukan pemotongan spesimen pada penampang melintang garis las. Hasil pengukuran cacat void dan Incomplete Penetration yang dilihat menggunakan macroscopy di penampang melintang garis las ditampilkan pada tabel 4.

Tabel 4. Ukuran cacat Hasil FSW Al 5083-H112 (Irfan,2016)

\begin{tabular}{|c|c|c|c|}
\hline \multirow[b]{2}{*}{ Bentuk Pin } & \multicolumn{3}{|c|}{ Cacat } \\
\hline & Defleksi & $\mathrm{IP}(\mathrm{mm})$ & $\begin{array}{l}\text { Void } \\
\left(\mathrm{mm}^{2}\right)\end{array}$ \\
\hline $\begin{array}{l}\text { Tirus } \\
\text { Beralur }\end{array}$ & $0^{\circ}$ & 1,23 & 3,02 \\
\hline $\begin{array}{l}\text { Silinder } \\
\text { Beralur }\end{array}$ & $0^{\circ}$ & 1,18 & 6,39 \\
\hline $\begin{array}{l}\text { Segitiga } \\
\text { Beralur }\end{array}$ & $0^{\circ}$ & 1,34 & 7,83 \\
\hline
\end{tabular}

Penggunaan pin tirus beralur, silinder beralur dan segitiga beralur pada proses FSW aluminium 5083 - H112 menunjukkan adanya cacat void dan Incomplete Penetration pada semua hasil lasan. Apabila gaya gesek dan penekanan yang dibutuhkan tidak cukup dan kecepatan pengelasan yang tinggi serta klem material kerja tidak kuat (gap terlalu besar) maka akan menyebabkan terbentuknya void. Desain pin yang tidak tepat (diameter pin yang terlalu besar) atau kecepatan pengelasan yang terlalu tinggi maka material yang terdeformasi akan dingin sebelum sepenuhnya mengisi daerah tepat di belakang too/ dan terbentuklah void.

Selain itu panas yang dihasilkan tidak cukup karena diameter shoulder tidak tepat atau tekanan tidak cukup maka material lunak tidak akan mengalir dengan baik dan akan membentuk void. Untuk menghindari munculnya void bisa dilakukan dengan membuat desain tool yang benar dan cocok untuk tiap-tiap jenis material serta dengan mengatur kecepatan pengelasan selain pemasangan klem yang benar.

Incomplete Penetration yang muncul pada hasil lasan menggunakan tool dengan pin tirus beralur, silinder beralur atau segitiga beralur disebabkan oleh desain tool yang tidak tepat seperti panjang pin yang terlalu pendek sehingga jarak antara ujung pin dengan bagian bawah tebal pelat terlalu besar sehingga panas yang dihasilkan akibat gesekan tidak cukup mampu melunakkan dan mengalirkan material sampai ke permukaan bawah material kerja (Maryati, 2016). Desain pin diusahakan sedekat mungkin dengan bagian bawah tebal pelat tapi jangan sampai merusak anvil.

\section{Analisis Hasil Uji Struktur Mikro}

Foto mikro dari pemeriksaan metalografi menggunakan mikroskop optik dengan perbesaran lensa objektif 10 pelat AA 5083 - H112 hasil lasan pada Gambar 8 menunjukkan terjadi perubahan struktur mikro pada masing-masing daerah lasan dan sekitarnya.

Hal ini terjadi karena panas yang diterima masing-masing daerah lasan berbeda-beda. Daerah yang berada di zona Weld Nugget memiliki ukuran butir yang lebih halus dan rapat dibandingkan dengan daerah sekitarnya seperti TMAZ dan HAZ serta Base Metal. Ukuran butir pada daerah TMAZ yang tidak mengalami rekristalisasi memiliki ukuran butir besar dibandingkan butir pada daerah Weld Nugget. Daerah HAZ yang mengalami pengaruh panas juga mengalami perubahan struktur mikro lebih besar dari pada ukuran butir daerah Base Metal (Wijayanto, 2011).

Perubahan ukuran butir yang terjadi ini disebabkan oleh pengaruh panas pada saat proses Friction Stir Welding. Sehingga terjadi pergerakan atom-atom dan akibat proses pendinginan yang cepat maka terbentuk ukuran butir yang lebih kecil. Untuk daerah sekitar lasan proses pendinginan berlangsung lebih lambat sehingga ukuran butir pada daerah HAZ cenderung lebih besar bahkan tidak terjadi perubahan pada daerah Base Metal.

Proses Friction Stir Welding menggunakan tool dengan pin berbentuk tirus beralur menghasilkan struktur mikro 
yang lebih halus dan rapat dibandingkan menggunakan pin berbentuk silinder beralur atau segitiga beralur. Hal ini akan meningkatkan sifat mekanik seperti kekuatan tarik dan kekerasan material hasil lasan yang dapat dilihat pada penjelasan berikutnya. Hasil foto struktur mikro menunjukkan bahwa menggunakan tool dengan pin berbentuk tirus beralur bisa menjadi pilihan yang baik dalam Friction Stir Welding untuk material aluminium 5083 - H112 dibandingkan menggunakan pin silinder beralur atau segitiga beralur.

\section{Analisis Hasil Pengujian Kekerasan}

Untuk melihat perubahan nilai kekerasan yang terjadi akibat adanya pengaruh panas setelah proses FSW maka dilakukan pengujian kekerasan menggunakan microvickers yang hasilnya dapat dilihat pada Gambar 9.

Hasil pengujian kekerasan menunjukkan bahwa kekerasan pada daerah Weld Nugget menggunakan pin tirus beralur pada proses FSW mempunyai nilai yang paling tinggi yaitu sebesar 85 HV. Walaupun kenaikan nilai kekerasan tersebut tidak terlalu besar terhadap logam induknya sekitar 74 HV. Hal ini menunjukkan bahwa proses Friction Stir Welding berlangsung dengan baik yaitu dapat meningkatkan sifat mekanik khususnya kekerasan material. Perubahan bentuk dan ukuran butir pada beberapa daerah lasan akan berpengaruh pada nilai kekerasannya. Daerah Weld Nugget dengan bentuk butir fine equiaxed mempunyai bentuk yang sama dan halus akan mempunyai nilai kekerasan yang lebih tinggi dibandingkan daerah sekitarnya karena semakin halus butir yang dihasilkan maka nilai kekerasan makin tinggi (Biswajit dkk, 2011).

Sedangkan daerah TMAZ yang berada tepat disebelah daerah lasan memiliki bentuk dan ukuran butir yang hampir sama dengan daerah Weld Nugget memiliki nilai kekerasannya tidak jauh berbeda dengan Weld Nugget.

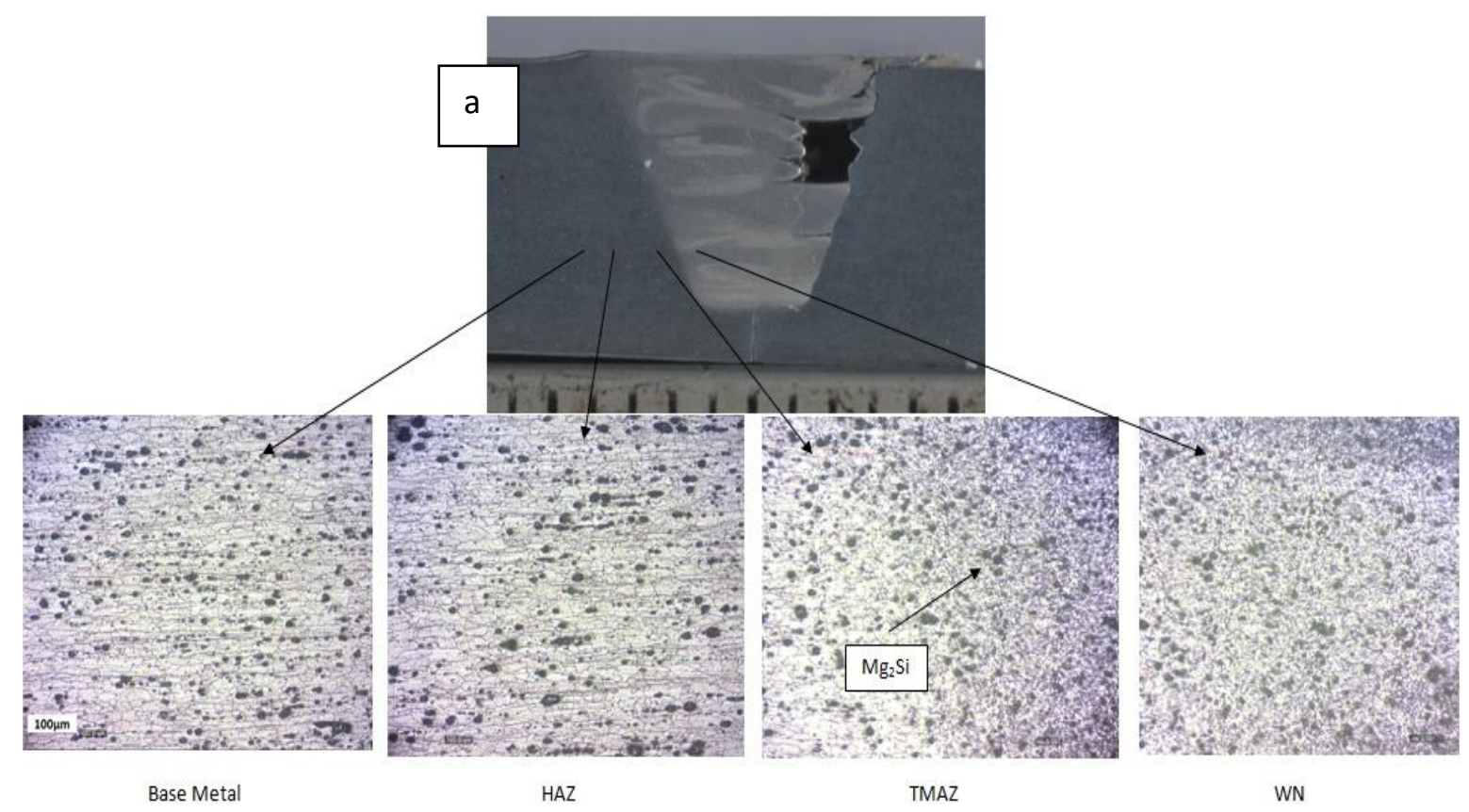



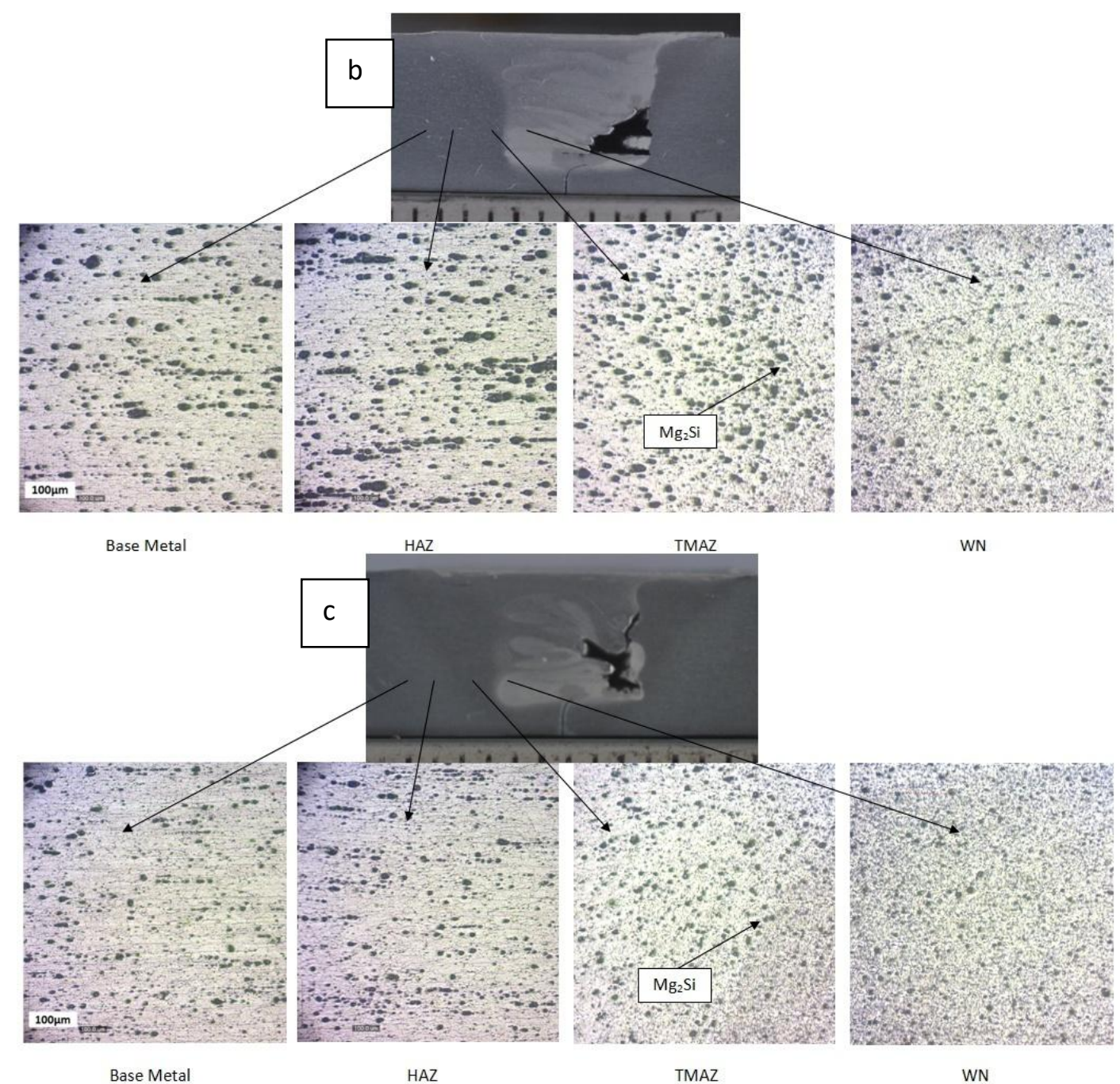

Gambar 8. Struktur mikro hasil proses FSW menggunakan pin a) tirus beralur b) silinder beralur c) segitiga beralur

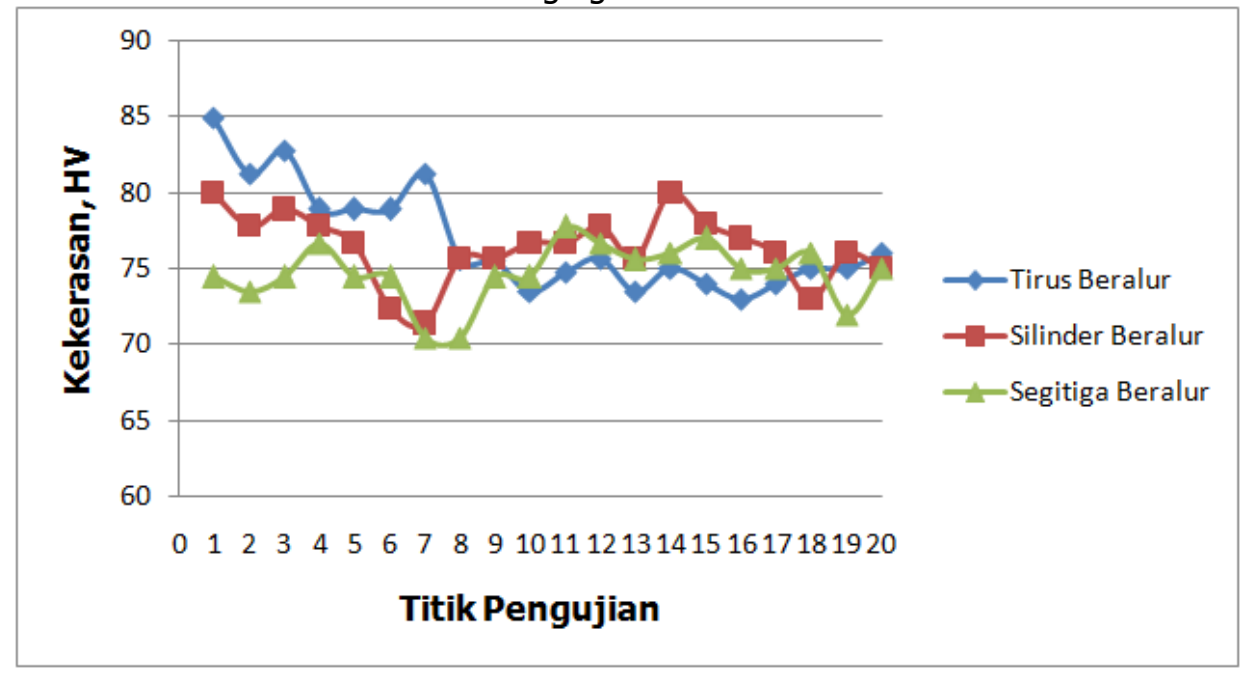

Gambar 9. Hasil uji kekerasan logam las

Pada daerah HAZ bentuk butir yang seperti oval dan membesar karena terpengaruh panas menyebabkan nilai kekerasan mendekati nilai kekerasan pada logam induk. 
Proses Friction Stir Welding yang berbeda telah menunjukkan bahwa penggunaan pin berbentuk tirus beralur menghasilkan kekerasan tertinggi dibandingkan dengan bentuk pin silinder beralur dan segitiga beralur sehingga dapat dijadikan pilihan untuk proses friction stir welding material aluminium $5083-\mathrm{H} 112$.

\section{Analisis Hasil Pengujian Tarik}

Untuk mengetahui besarnya kekuatan tarik hasil proses FSW Aluminium 5083 - H112 maka dilakukan pengujian pada beberapa posisi sepanjang lasan menggunakan ketiga jenis bentuk pin dengan pemotongan spesimen pada beberapa posisi penampang melintang lasan. Pada penelitian ini ada tiga posisi penampang melintang yang diuji untuk masing - masing pin yang digunakan. Penampang melintang pada awal pengelasan disimbolkan dengan $A$, penampang melintang pada pertengahan lasan disimbolkan dengan $\mathrm{T}$ dan penampang melintang pada titik akhir lasan disimbolkan dengan S. Hasil pengujian tarik dapat dilihat pada Gambar 10.

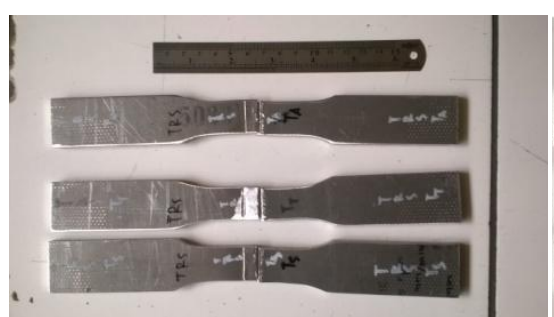

Tirus Beralur

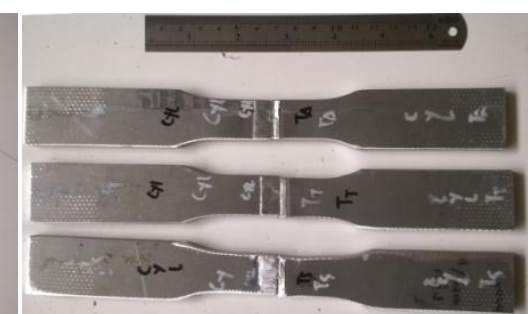

Silinder Beralur

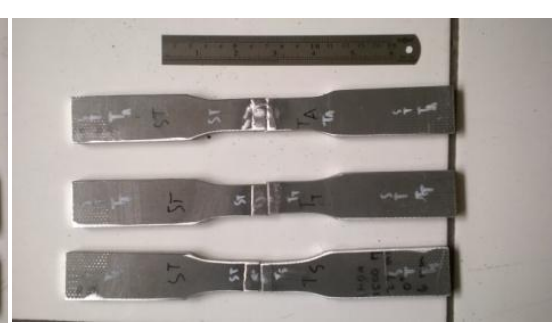

Segitiga Beralur

Gambar 10. Patahan pada spesimen uji tarik menggunakan pin berbeda

Hasil pengujian kekuatan tarik dapat dilihat pada Gambar 11 berikut.

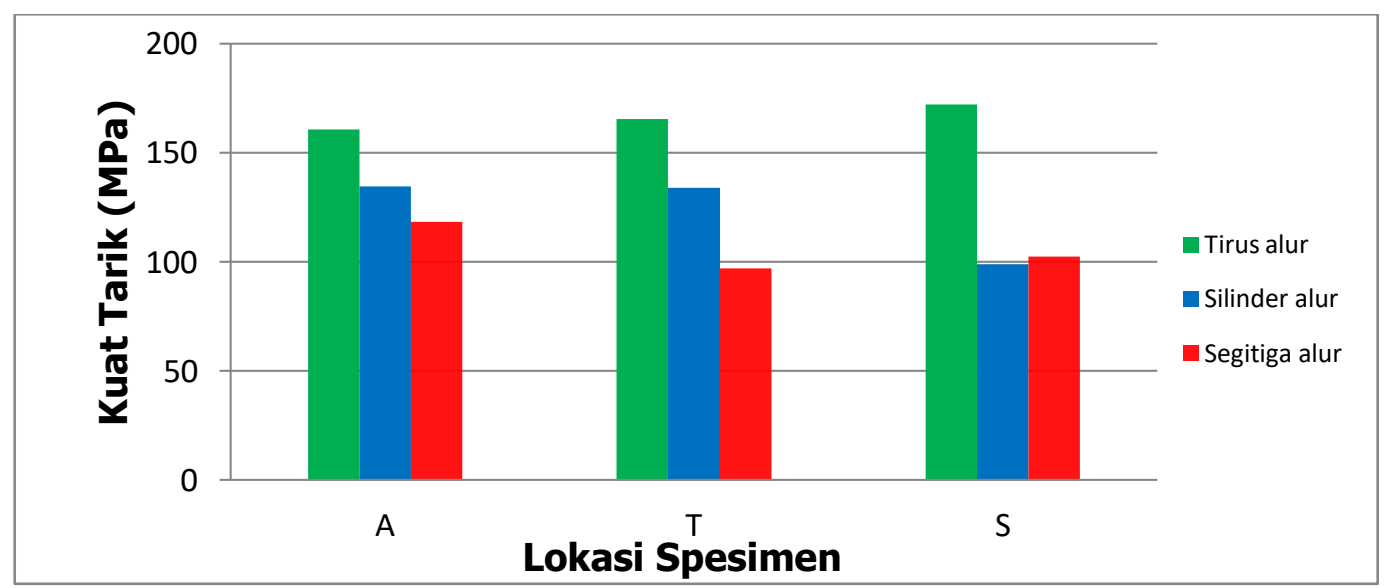

Gambar 11. Hubungan kekuatan tarik proses FSW aluminium 5083 - H112 terhadap penggunaan pin berbeda

Dari hasil uji tarik didapatkan bahwa kekuatan tarik maksimum diperoleh menggunakan pin tirus beralur yaitu sebesar $172 \mathrm{MPa}$. Hal ini terjadi karena pengadukan material lunak yang merata sesuai dengan bentuk pin yang digunakan. Sedangkan menggunakan pin segitiga nilai kekuatan tarik menjadi rendah karena pengadukan material lunak yang tidak merata sehingga adanya cacat akan mengurangi nilai kekuatan tarik lasan.

Apabila dibandingkan dengan kekuatan tarik dari Base Metal yang besarnya $331 \mathrm{MPa}$, hasil uji tarik menggunakan tiga variasi pin tersebut ada 
di bawahnya. Hal ini menunjukkan bahwa proses FSW akan menurunkan kekuatan tarik pelat aluminium 5083 - H112 tersebut karena adanya cacat pada hasil lasan yang menyebabkan luas daerah yang mampu menahan beban tarik menjadi lebih kecil.

\section{Analisis Hasil Pengujian Impak}

Untuk mengetahui besarnya harga impak hasil proses FSW Aluminium 5083 H112 maka dilakukan pengujian pada tiga titik lasan yang diuji untuk masing masing pin yang digunakan dan hasilnya ditunjukkan oleh Gambar 12.

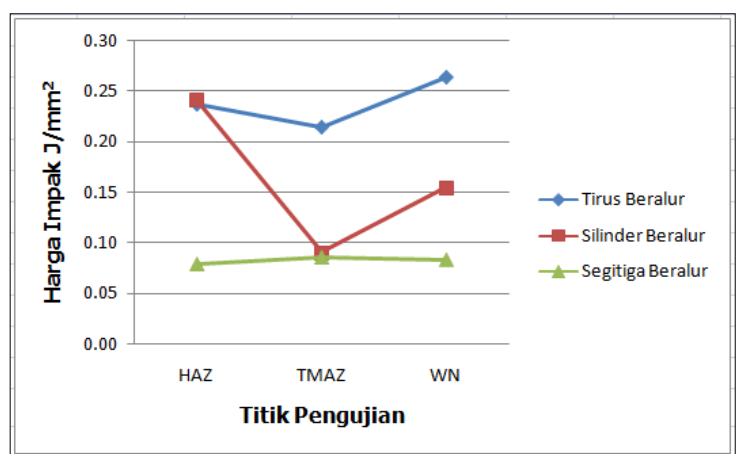

Gambar 12. Hasil uji impak logam las

Harga impak terbesar diperoleh menggunakan pin tirus beralur yaitu $0,27 \mathrm{~J} / \mathrm{mm}^{2}$, lebih besar dari harga impak logam induk sebesar $0,2 \mathrm{~J} / \mathrm{mm}^{2}$ sedangkan harga terendah adalah $0,07 \mathrm{~J} / \mathrm{mm}^{2}$ menggunakan pin segitiga beralur.

Hasil pengujian impak menggunakan tool bentuk silinder beralur untuk ketebalan pelat $6 \mathrm{~mm}$ menunjukkan bahwa rata-rata harga impak menggunakan tool bentuk silinder beralur lebih besar dari pada menggunakan pin segitiga beralur tetapi lebih rendah dibandingkan menggunakan pin tirus beralur. Secara umum harga impak menggunakan tool silinder beralur berada dibawah harga impak logam induk atau Base Metal.

Harga impak menggunakan tool segitiga beralur yang didapat dari pengujian memiliki nilai rata-rata paling rendah dan berada dibawah harga rendah dan berada dibawah harga impak Base Metal dengah harga impak terbesar adalah $0,11 \mathrm{~J} / \mathrm{mm}^{2}$ sedangkan terendahnya adalah $0,07 \mathrm{~J} / \mathrm{mm}^{2}$. Hal ini terjadi karena pengadukan tool segitiga beralur tidak sebagus mengunakan too/ silinder beralur atau tirus beralur.

Secara keseluruhan besarnya harga impak yang didapat dari penggunaan bermacam bentuk pin dan ketebalan menunjukkan bahwa proses FSW menggunakan tool dengan pin berbentuk tirus beralur menghasilkan harga impak paling optimum. Hasil ini menegaskan hasil pengujian sebelumnya yang menunjukkan bahwa penggunaan tool dengan pin tirus beralur memberikan hasil yang lebih baik dibanding menggunakan pin bentuk silinder atau segitiga beralur. Hal ini ditunjukkan pada daerah lasan dan TMAZ yang memiliki butir lebih halus daripada daerah HAZ, karena semakin halus butir yang dihasilkan maka energi yang dibutuhkan untuk mendeformasi material juga makin besar. Dari hasil pengujian juga dapat dilihat bahwa harga impak pada daerah Weld Nugget dan TMAZ memiliki nilai yang hampir sama.

\section{KESIMPULAN DAN SARAN Kesimpulan}

Berdasarkan hasil pengujian mekanik dan struktur mikro hasil proses FSW aluminium 5083 - H112 dapat disimpulkan bahwa proses FSW aluminium 5083 - H112 telah berhasil dilakukan dengan baik dan parameter proses FSW putaran 1500 rpm, kecepatan pengelasan $29 \mathrm{~mm} / \mathrm{min}$, sudut inklinasi tool $0^{\circ}$ menggunakan too/ dengan bentuk tirus beralur, silinder beralur dan segitiga beralur belum memberikan hasil yang optimal dan dapat dilihat dari hasil pengujian mekanik munculnya cacat void dan IP pada hasil lasandan terjadi penurunan kekuatan tarik maksimum 172 Mpa terhadap logam induk sebesar 331 Mpa.

Terjadi perubahan struktur mikro di setiap area atau zone lasan untuksetiap penggunaan bentuk pin yang berbeda.

Tool dengan bentuk profil pin berbeda - beda akan memberikan hasil yang berbeda dari segi sifat mekanik dan struktur mikronya. Proses FSW aluminium 5083 - H112 menggunakan tool dengan bentuk pin tirus beralur menghasilkan sifat 
mekanik maupun struktur mikro yang lebih baik dibandingkan menggunakan tool bentuk pin silinder beralur atau segitiga beralur.

\section{Saran}

Buat simulasi aliran material menggunakan software Ansys Fluent dengan variasi putaran dan kecepatan pengelasan untuk memastikan tidak timbulnya cacat saat proses FSW berlangsung. Untuk menghindari void gunakan kecepatan pengelasan yang lebih rendah. Desain tool dengan panjang pin yang mendekati tebal plat. Variasikan parameter lain untuk mendapatkan hasil yang lebih akurat.

\section{UCAPAN TERIMA KASIH}

Penulis mengucapkan terima kasih yang sebesar-besarnya kepada Bapak Dr. Slameto Wiryolukito, BBLM dan Laboratorium Produksi ITB yang menyediakan waktu dan fasilitas untuk penelitian ini.

\section{DAFTAR PUSTAKA}

ASM Handbook Volume 2, 2004, Properties and Selection: Non Ferous Alloy and Special Pupose Materials AWS D17.3/D17.3M, 2010, Specification For Friction Stir Welding of Aluminium Alloys For Aerospace Application.

ESAB, 2012, Technical Handbook : Friction Stir Welding.

Harimurti Victor, 2014, Pengaruh Profil Pin terhadap Sifat Mekanik Dan Struktur Mikro Sambungan Pelat Aluminium 5083 Pada Proses Friction Stir Welding, Tugas Akhir Program Sarjana Universitas Sebelas Maret Irfan, 2016 Analisis Hasil Proses Friction Stir Welding Aluminium 5083 - H112 Dengan Variasi Bentuk Pin Tesis Pascasarjana ITB.

Khaled Terry, 2005, An Outsider Looks At Friction Stir Welding, REPORT \#: ANM-112N-05-06, Federal Aviation Administration.

Biswajit Parida, Sukhomay Pal, Pankaj Biswas, M M Mohapatra, Sujoy
Tikader, 2011, Mechanical and Micro-structural Study of Friction Stir Welding of Al-alloy International Journal of Applied Research In Mechanical Engineering (IJARME), ISSN: 2231 -5950 Volume-1, ssue-2.

Maryati, 2016, Pengaruh Kecepatan Putaran Tool Terhadap Sifat Mekanik dan Struktur Mikro Hasil Pengelasan Metode Friction Stir Welding Pada Aluminium 50837075, Tesis Pascasarjana Universitas Indonesia.

Rahayu Deden, 2012, Analisis Proses Friction Stir Welding (FSW) Pada Plat Tipis Aluminium Tugas Akhir Program Sarjana, Universitas Indonesia.

Rajiv S. Mishra, Murray W. Mahoney, 2007 Friction Stir Welding and Processing, ASM international .

R.S. Mishra, Z.Y. Ma, 2005, Friction stir Welding and processing, Materials Science and Engineering $R 50$ 1-78.

Tarmizi, Prayoga B, 2016 Analisis Sifat Mekanik Dan Struktur Mikro Pada Proses Friction Stir Welding Alumunium Seri 5052, Jurnal Riset Industri Vol.10 No.2 hal 70-82.

Wijayanto W, 2013, Pengaruh Sudut Kemiringan Tool Terhadap Sifat Mekanik Dan Struktur Mikro Sambungan Pelat AA 5083 Pada Proses Friction Stir Welding, Tugas Akhir Program Sarjana Universitas Sebelas Maret.

Wiryosumarto H \& Thosie Okumura, 2000, Teknologi Pengelasan logam, Jakarta, Pradnya Paramita. 